\title{
Recurrence of multicystic ameloblastoma: case report
}

\author{
Recorrência de ameloblastoma multicístico: relato de caso
}

\author{
Juliana Dreyer da Silva de Menezes* \\ Renato Yassutaka Faria Yaedú* \\ Ana Carolina Valente ${ }^{* * *}$ \\ Marco Oliveira ${ }^{* * *}$ \\ Luis Antônio de Assis Taveira ${ }^{* * * *}$ \\ Isabel Regina Fischer Rubira Bullen ${ }^{* * * * *}$
}

\begin{abstract}
Introduction: The WHO classifies ameloblastoma as a benign epithelial odontogenic tumor without odontogenic ectomesenchyme with locally invasive behavior and high recurrence rate. It represents $1 \%$ of oral tumors, primarily affecting the posterior mandible. Generally slow growing and asymptomatic, it can perforate the cortical bone, reabsorb and move teeth, and cause facial asymmetry. Classification may be given, according to clinical and radiographic aspects, as solid or multicystic, cystic, and peripheral ameloblastoma. Objectives: To report a case of multicystic ameloblastoma treated with marginal resection of the mandible. Case report: 34-year-old patient referred for assessment of multiloculated radiolucent lesion involving areas of the body, angle, and right mandibular ramus, revealing by histopathological examination the diagnosis of ameloblastoma. The patient underwent resection surgery and reconstruction plate fixation for layer maintenance. Eighteen months after surgery, there were no clinical or radiographic signs. Final considerations: The interpretation of clinical and imaging data of patients with ameloblastoma is essential for early diagnosis and effective treatment of the lesion. Follow-up with regular visits is an essential part of treatment, considering their local aggressiveness and high recurrence rate.
\end{abstract}

Keywords: Ameloblastoma. Mandible. Diagnosis.

\section{Introduction}

Ameloblastoma is an odontogenic tumor that grows slowly, but is locally invasive and infiltrating $^{1-3}$. It has a destructive potential and the combination of proliferative lesions to malignant transformation have been documented ${ }^{4,5}$. Its etiology is not completely understood, but is believed to be originated from the remaining dental lamina, reduced enamel epithelium, epithelial cell rests of Malassez, or from the basal cells of the epithelial surface layer $^{5,6}$. There is no prevalence for gender or race, and it affects predominantly the mandible (80-85\% of cases $)^{7}$.

The solid or multicystic ameloblastoma is a subtype that shows a greater tendency to infiltrate the surrounding tissues. It shows a higher recurrence rate, and requires quick and precise approach for treatment implementation ${ }^{1-8}$. Thus, once the diagnosis is established, the treatment plan is drawn from the clinical and radiographic findings, and may be aided by $\mathrm{CT}$ and $\mathrm{MRI}^{1-9}$.

By presenting unique biological behavior, there is controversy about the best way to treat ameloblastomas. Several therapeutic modalities have been proposed, including curettage, marsupialization, cryosurgery, electrocautery, sclerotherapy, and radiotherapy. However, the conventional treatment for solid ameloblastomas, in most cases, is radical

PhD, Departament of Diagnosis and Surgery, São Paulo State University, Araraquara, SP, Brazil.

PhD, Associate Professor, Departament of Stomatology, Dentistry School, São Paulo University, Bauru, SP, Brazil.

MS Oral Rehabilitation, Hospital for Rehabilitation of Craniofacial Anomalies Bauru School of Dentistry, University of São Paulo, Bauru, SO, Brazil.

MS Oral Rehabilitation, Hospital for Rehabilitation of Craniofacial Anomalies Bauru School of Dentistry, University of São Paulo, Bauru, SO, Brazil.

PhD, Associate Professor, Departament of Stomatology, Dentistry School, São Paulo University, Bauru, SP, Brazil.

PhD, Associate Professor, Departament of Stomatology, Dentistry School, São Paulo University, Bauru, SP, Brazil. 
surgical excision with 1 to $2 \mathrm{~cm}$ of safety margin beyond the limits of the radiographic lesion ${ }^{1,2,10}$.

Radical techniques bring with them serious inconvenience to the patient, including masticatory dysfunction, change of mandibular movements, and facial mutilation and deformity ${ }^{11}$. Treatment should include rehabilitation, restoring functional, anatomical, and esthetic abilities, as well as assisting the reintegration of the patient to society ${ }^{12}$.

This study aims to report the case of multicystic ameloblastoma treated with marginal resection of the mandible, and to discuss relevant issues regarding diagnosis and treatment of this condition.

\section{Case report}

A 34-year-old patient was referred to the Stomatology service at the Bauru School of Dentistry of the University of São Paulo (USP), Brazil, for assessment of multilocular radiolucent lesion involving the areas of the body, angle, and the right mandibular ramus. Clinically, the lesion was covered with mucosa of regular color and there was no facial asymmetry (Figure 1).

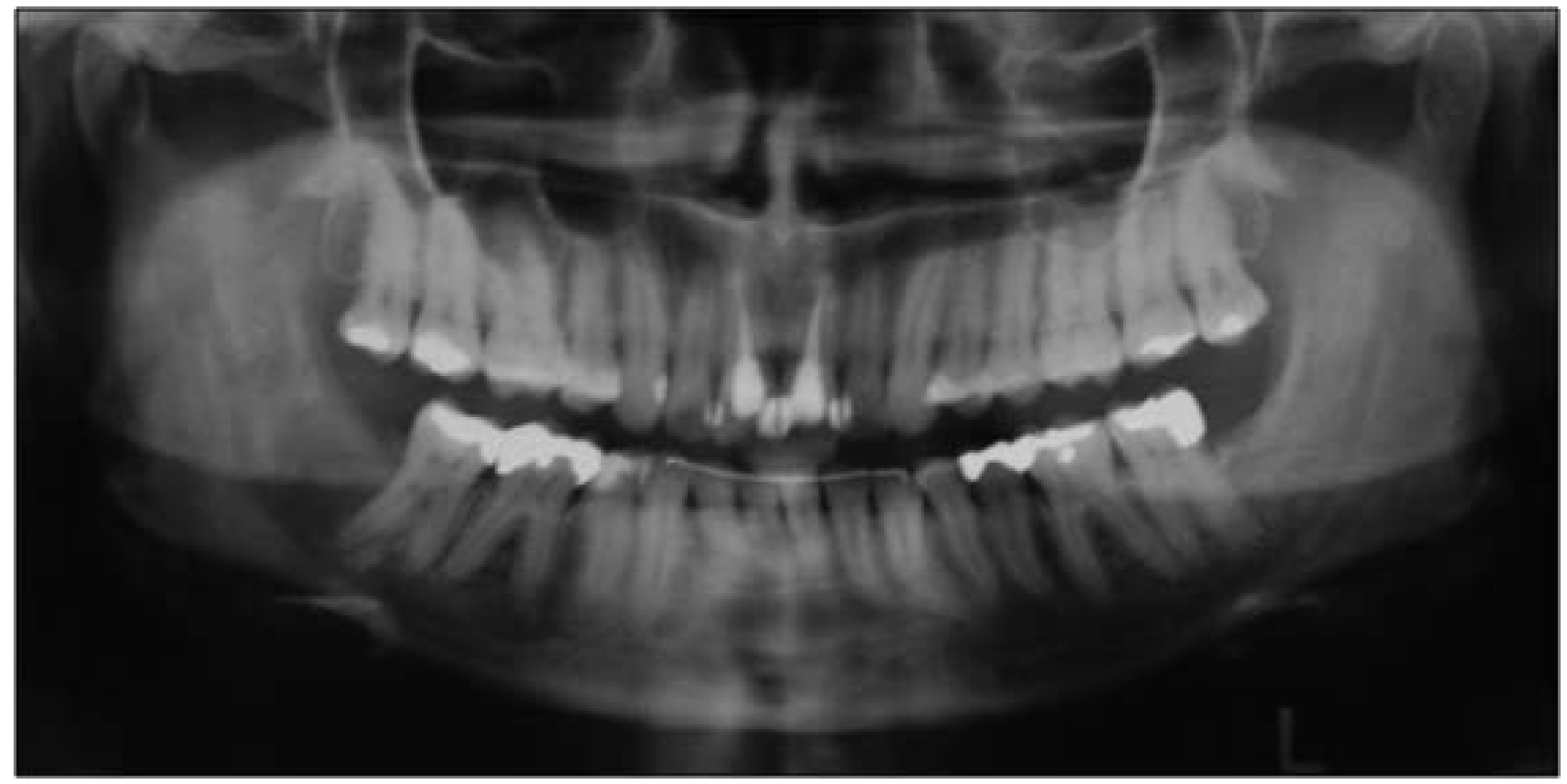

Figure 1 - Initial panoramic radiograph

Source: all figures are prepared by the authors.

Marsupialization was performed to collect material for biopsy and diagnosis was pulse granuloma. After 4 months, the lesion receded (Figure 2).

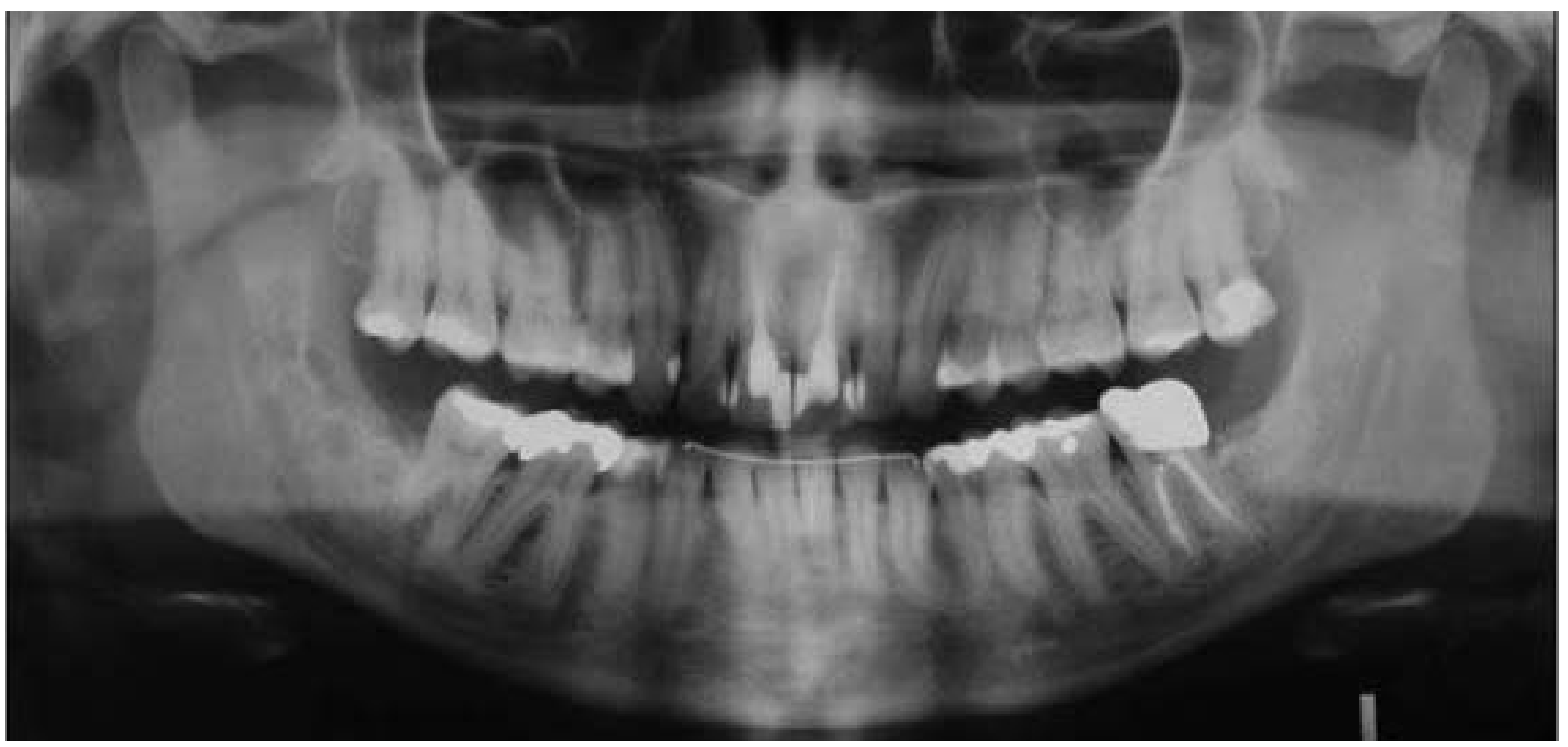

Figure 2 - Panoramic radiograph after marsupialization 
In the clinical and radiographic postoperative control after one year, multilocular radiolucent area in the mandibular angle was observed (Figure 3).

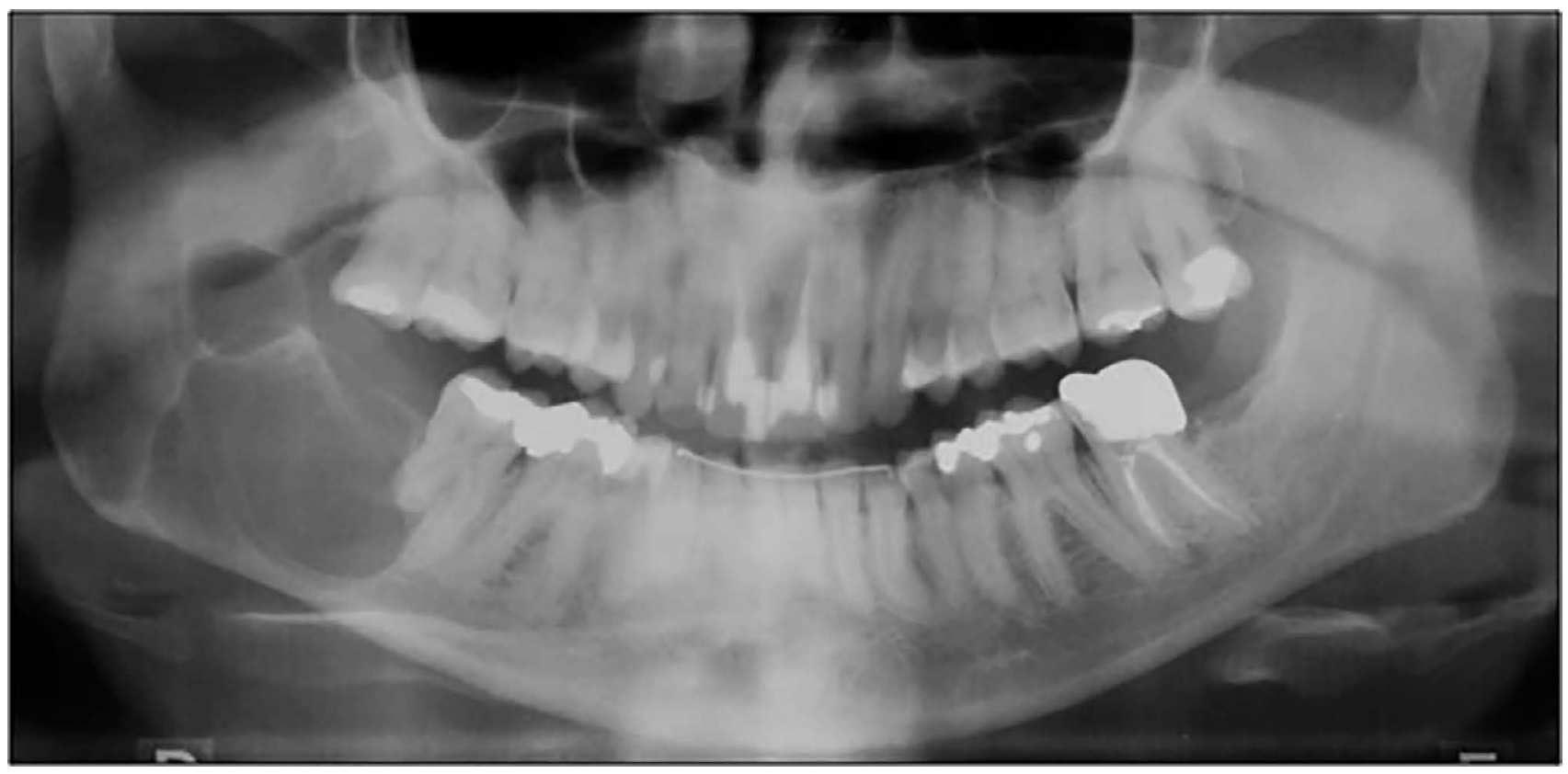

Figure 3 - Radiograph showing the recurrence of the lesion

New biopsy was performed and the histopathological examination revealed an ameloblastoma. The patient underwent a surgical procedure via three-dimensional margin resection including larger cortical and medullary portion of the mandibular body and ascending ramus, preserving the base of the mandible and the posterior region of the ascending ramus. A $2.4 \mathrm{~mm}$ reconstruction plate system was fixed, overlapping the lower residual cortical bone for maintenance of the surgical site (Figure 4).
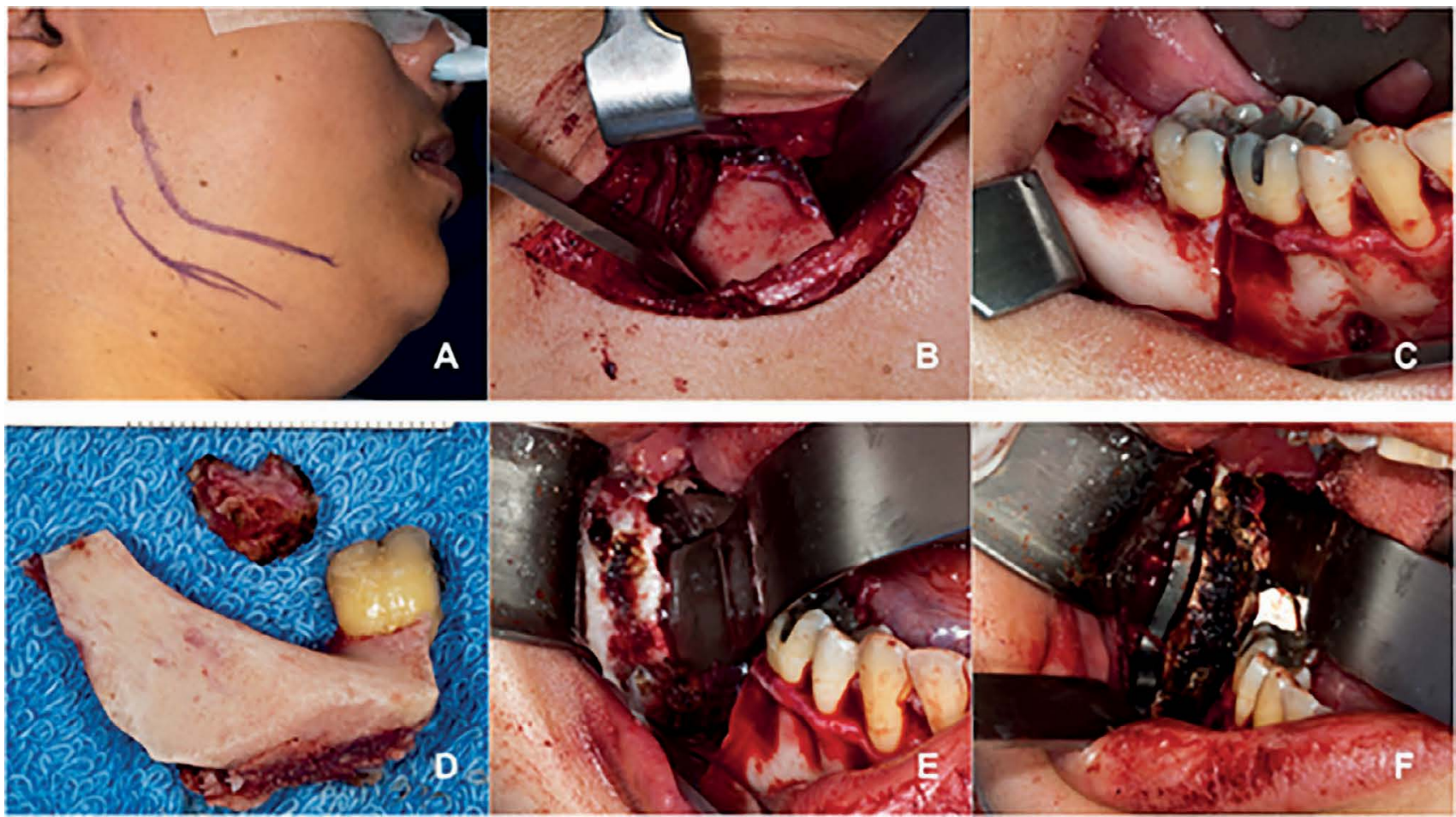

Figure 4 - Surgical sequence of marginal resection on the right side of the mandible

A: Demarcation of the incision line; B: Submandibular approach; C: Intraoral view of marginal resection; D: Specimen of the partially resected portion of the right mandible; E: Cauterization after marginal resection; $\mathrm{F}$ : Osteosynthesis using reconstructive titanium plate and screws. 
Postoperative controls were conducted every three months, and 20 months after the surgery the patient returned for postoperative control without signs and symptoms of recurrence (Figure 5).

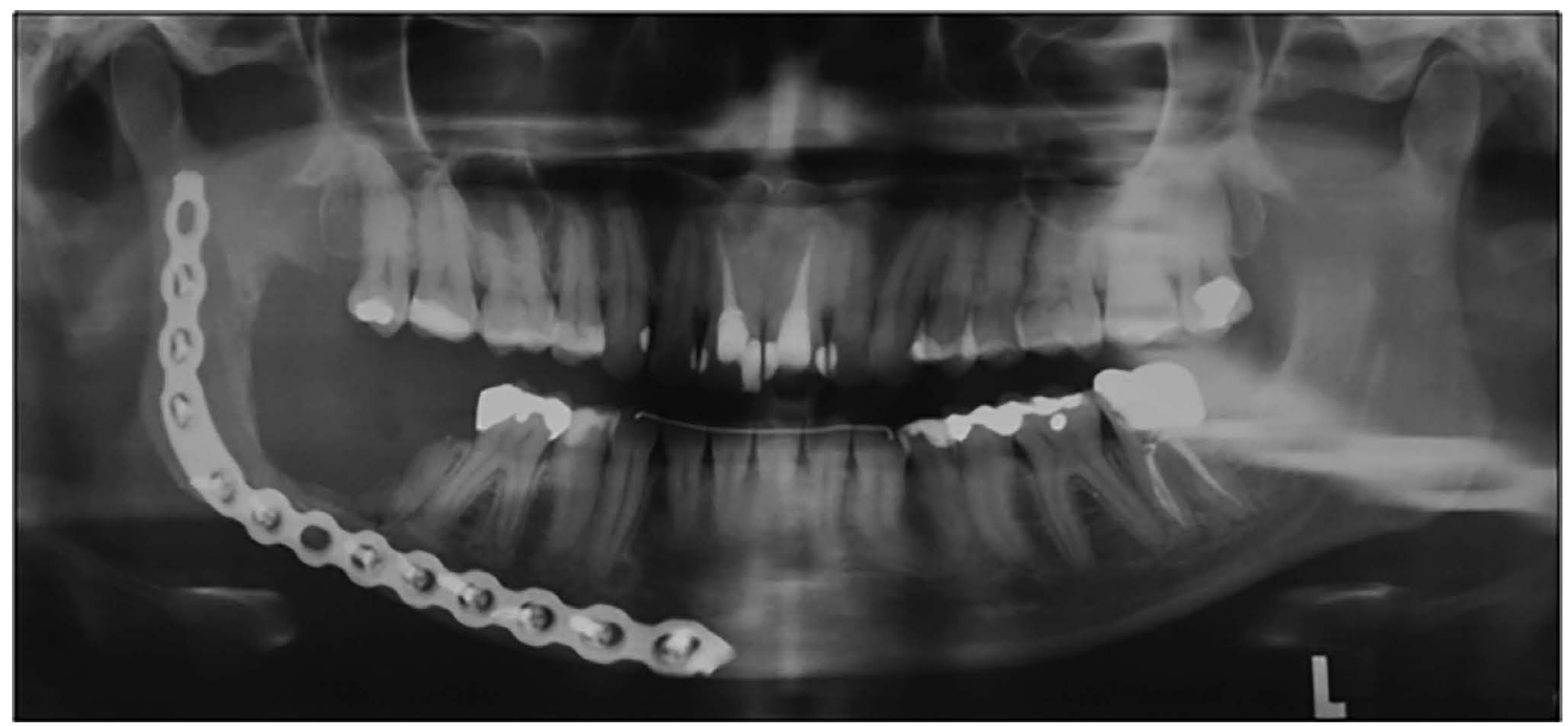

Figure 5 - Postoperative radiograph (1 year)

\section{Discussion}

The WHO classifies ameloblastoma as a benign epithelial odontogenic tumor without ectomesenchyme with locally invasive behavior and a high recurrence rate. It represents 11 to $18 \%$ of all odontogenic tumors primarily affecting the posterior mandible $^{6-13}$. Generally asymptomatic and slow growing, it can perforate the cortical bone, resorb teeth, and cause facial asymmetry ${ }^{1}$.

Odontogenic cysts and tumors are a group of lesions arising from the tooth-producing apparatus or its remnants. They may originate from odontogenic epithelium and/or ectomesenchyme with varying degrees of inductive tissue interaction ${ }^{14-16}$. Odontogenic cysts and tumors are rare, and the lack of familiarity with these lesions and their variable appearance may lead to difficulties in diagnosis, with occasional serious confusion with other lesions. Thus, the clinician should perform a careful biopsy, with sufficient amount of tissue, avoiding misinterpretation of the histopathological examination due to lack of material, as probably occurred in the first biopsy $^{12,17,18}$.

Ameloblastomas are classified into unicystic, multicystic, peripheral, and malignant subtypes, whereas conventional ones are solid or multicystic ( $86 \%$ of cases), unicystic ( $13 \%$ of cases), and peripheral or extra-osseous (about $1 \%$ of cases) (6). Such distinction is important, as it aids treatment selection.

Conventional ameloblastoma tends to infiltrate the bone trabeculae of cancellous bone in the periphery of the lesion, prior to bone resorption being visible radiographically. Therefore, the true tumor margin often extends beyond the apparent clinical or radiographic margin ${ }^{2}$.

The best form of treatment has been controversial for several years. Radiotherapy is not indicated because the lesion is radioresistant. There is also an indication in the literature of electrocautery, cryosurgery, and injection of sclerosing agents as alternative treatments ${ }^{9,16}$.

A high potential for recurrence (60 to $80 \%$ ) after simple treatment with enucleation or curettage is frequently observed, justifying the choice of professionals for more aggressive treatments ${ }^{10}$. An adequate alternative for the treatment of small lesions of multicystic ameloblastoma is marginal resection, which is widely used; however, due to the recurrence rate of approximately $15 \%$, it is recommended that the safety margin should be at least $1 \mathrm{~cm}$ beyond the radiographic limits ${ }^{6}$.

Evaluating several studies in order to compare the recurrence rate of treatments with complete and marginal resection, no significant difference was observed between the approaches ${ }^{16,17}$.

The advantages of less extensive surgical treatments such as marginal resection of the mandible are significant, improving patient prognosis. Facial deformity, masticatory dysfunction, abnormal jaw movement, and the need for further reconstructive surgeries are consequences often associated with treatments of complete resection, and may often be minimized with the use of marginal resection ${ }^{10,14}$. However, cases of extensive lesions affecting great part of the maxillary cortical bone or mandibular lesions by anatomic considerations suggest a more 
aggressive approach with segmental resection (without maintaining bone continuity) including periosteum and overlying soft tissues ${ }^{15,16,17}$.

The interpretation of clinical and imaging data of patients with ameloblastoma is essential for early diagnosis and effective treatment of the lesion. The therapeutic decision must aim to eliminate the pathology, considering the morbidity of treatment method and the quality of life in the rehabilitation of patients ${ }^{15,18}$.

The long-term postoperative follow-up with imaging is essential because, although more than $50 \%$ of recurrences happen within the first five postoperative years, the lesion has the potential to develop late recurrences ${ }^{2,9,18}$. Due to its slow growth, the reappearance of the lesion may occur after many years or even decades from the first surgery, and when this happens, the lesions tend to show a higher potential for invasion and bone destruction than the original ones ${ }^{15}$.

\section{Conclusions}

The treatment by marginal resection with a safety margin was an efficient alternative in this reported case of multicystic ameloblastoma in the mandible, avoiding mutilation by a more radical treatment. Although the conservative approach proved itself effective so far in the case described, the long-term follow-up is an essential part of treatment considering their local aggressiveness and high recurrence rate.

\section{Resumo}

Introdução: o ameloblastoma é classificado pela Organização Mundial de Saúde (OMS) como um tumor odontogênico epitelial benigno sem ectomesenquima odontogênico com comportamento localmente invasivo e alta taxa de recorrência. Representa $1 \%$ dos tumores orais, afetando principalmente a região posterior da mandíbula. Geralmente assintomático, de crescimento lento, pode perfurar a cortical óssea, reabsorver e movimentar dentes e causar assimetria facial. Esse tipo de tumor pode ser classificado, de acordo com os aspectos clínicos e radiográficos, em ameloblastoma sólido ou multicístico, unicístico e periférico. Objetivo: relatar um caso de ameloblastoma multicístico tratado com ressecção marginal da mandíbula. Relato de caso: paciente de 34 anos encaminhado para avaliação de lesão radiolúcida multiloculada envolvendo as regiões de corpo, ângulo e ramo mandibular direito, revelando ao exame histopatológico o diagnóstico de ameloblastoma. O paciente foi submetido à cirurgia ressectiva e à fixação com placa reconstrutiva para a manutenção do leito. Após dezoito meses de cirurgia não foram observados sinais clínicos ou radiográficos. Considerações finais: a interpretação dos dados clínicos e imaginológicos de pacientes com ameloblastoma é essencial para o diagnóstico precoce e o tratamento eficaz da lesão. $O$ acompanhamento com consultas periódicas é uma parte essencial do tratamento, considerando a agressividade local e a alta taxa de recorrência desse tipo de lesão.

Palavras-chave: Ameloblastoma. Mandíbula. Diagnóstico.

\section{References}

1. Scholl RJ, Kellett HM, Neumann DP, Lurie AG. Cysts and cystic lesions of the mandible: clinical and radiologic-histopathologic review. Radio-Graphics 1999; 19:1107-24.

2. Bataineh AB. Effect of preservation of the inferior and posterior borders on recurrence of ameloblastomas of the mandible. Oral Surg Oral Med Oral Pathol Oral Radiol Endod 2000; 90:155-63.

3. Tamme T, Tiigimäe J, Leibur E. Mandibular ameloblastoma: a 28-years retrospective study of the surgical treatment results. Minerva Stomatol 2010; 59:637-43.

4. Darshani Gunawardhana KS, Jayasooriya PR, Rambukewela IK, Tilakaratne WM. A clinic-pathological comparison between mandibular and maxillary ameloblastomas in Sri Lanka. J Oral Pathol Med 2010; 39:236-41.

5. Kotrashetti VS, Kale AD, Bhalaerao SS, Hallikeremath SR. Histopathologic changes in soft tissue associated with radiographically normal impacted third molars. Indian J Dent Res 2010; 21:385-90.

6. Neville BW, Damn DD, Allen CM, Bouquot JE. Patologia oral \& maxilofacial. 2. ed. Rio de Janeiro: Guanabara Koogan; 2004.

7. Hertog D, Schulten EA, Leemans CR, Winters HA, Van der Waal I. Management of recurrent ameloblastoma of the jaws; a 40-year single institution experience. Oral Oncol 2011; 47:145-6.

8. Curi MM, Dib LL, Pinto DS. Management of solid ameloblastoma of the jaws with liquid nitrogen spray cryosurgery. Oral Surg Oral Med Oral Pathol Oral Radiol Endod 1997 Oct; 84(4):339-44.

9. Fregnani ER, da Cruz Perez DE, de Almeida OP, Kowalski LP, Soares FA, de Abreu Alves F. Clinicopathological study and treatment outcomes of 121 cases of ameloblastomas. Int J Oral Maxillofac Surg 2010; 39:145-9.

10. Pogrel MA, Montes DM. Is there a role for enucleation in the management of ameloblastoma? Int J Oral Maxillofac Surg 2009 Aug; 38(8):807-12.

11. Chem RC, Wagner JC, Volkweis MR, Valente DS, Valente DS, Grandi G, et al. Uso de retalho livre de fíbula no complexo bucomaxilofacial. Relato de dois casos. Rev Cir Traumatol Buco-Maxilo-Fac 2005; 5(4):23-30.

12. Zemann W, Feichtinger M, Kowatsch $\mathrm{E}$ et al. Extensive ameloblastoma of the jaws: surgical management and immediate reconstruction using microvascular flaps. Oral Surg Oral Med Oral Pathol Oral Radiol Endod 2007; 103:190-6.

13. Gardner DG. Some current concepts on the pathology of ameloblastomas. Oral Surg Oral Med Oral Pathol Oral Radiol Endod 1996; 82:660-9.

14. Nakamura N, Higuchi Y, Mitsuyasu T, Sandra F, Ohishi M. Comparison of longterm results between different approaches to ameloblastoma. Oral Surg Oral Med Oral Pathol Oral Radiol Endod 2002; 93:13-20.

15. Sammartino G, Zarrelli C, Urciuolo V, di Lauro AE, di Lauro F, Santarelli A et al. Effectiveness of a new decisional algorithm in managing mandibular ameloblastomas: A 10-years experience. Br J Oral Maxillofac Surg 2007; 45:306-10. 
16. Rosenstein T, Pogrel MA, Smith RA, Regezi, JA. Cystic ameloblastoma: behavior and treatment of 21 cases. J Oral Maxillofac Surg 2001; 59:1311-6.

17. Hong J, Yun PY, Chung IH, Myoung H, Suh JD, Seo BM et al. Long-term follow up on recurrence of 305 ameloblastoma cases. Int J Oral Maxillofac Surg 2007; 36:283-8.

18. Slater LJ. Diagnostic criteria for unicystic ameloblastoma: ameloblastic versus ameloblastomatous epithelium. Oral Surg Oral Med Oral Pathol Oral Radiol Endod 2011; 111:536.

Correspondence address:

Juliana Dreyer da Silva de Menezes

Avenida Geraldo de Campos Barros, 60, Bloco 4,

apto. 201

14801375 Araraquara, São Paulo, Brazil

Telefone: (14) 98126-5110

E-mail: dreyer.ju@gmail.com

Recebido: 30/04/15. Aceito: 16/12/15. 